\title{
Pancreaticoduodenectomy for periampullary tumors at Dr. Cipto Mangunkusumo Hospital, Jakarta
}

\author{
Toar JM Lalisang, Arnold Simanjuntak, Bennardus Philippi
}

\begin{abstract}
Abstrak
Kami melaporkan hasil 31 pankreatikoduodenektomi dari 141 tumor periampula pada peroide 1994-2002. Di antara kasus, terdapat 16 perempuan; rentang usia 17-68 tahun. Ikterus adalah keluhan tersering, 14 penderita dengan kadar albumin di bawah 3,5 g/dl dan 10 penderita dengan kadar bilirubin lebih dari $10 \mathrm{mg} / \mathrm{dl}$. Telah dilakukan 17 Whipple klasik, 11 pankreatiokoduodenektomi dengan preservasi pilorus dan 3 total pankreatektomi+duodenektomi. Rerata lama operasi 436 menit (290-570). Penderita dikelompokkan dalam 2 periode, antara 1994-1999 dan sesudahnya. Dengan meningkatnya pengalaman, perdarahan intra operatif menurun dari rerata 2000 $\mathrm{ml}$ ke $400 \mathrm{ml}$. Gambaran histopatologi menunjukkan 11 adeno karsinoma kaput pankreas, 11 adeno karsinoma ampula Vater, 4 adeno karsinoma duodenum, 2 kista jinak kaput pankreas dan 3 tumor jinak. Mortalitas operatif terjadi pada 4 penderita dari 12 penderita periode pertama, dan hanya 1 pada 19 penderita sisanya. Komplikasi tersering adalah kebocoran anastomosis ke pankreas yang terjadi pada 14 penderita, dan 4 dari kebocoran tersebut menyebabkan mortalitas operatif. Rentang rawat antara 12 - 47 hari pasca bedah. Sampai akhir laporan ini, 7 penderita hidup tanpa penyakit, dan 4 penderita putus kontak. Rekurensi terjadi pada 13 penderita dari 22 penderita yang terjadi antara 4-24 bulan sesudah operasi, dan 12 penderita meninggal 2-3 minggu kemudian. Tiga penderita meninggal karena sebab yang lain. Kesimpulan: pankreatikoduodenektomi adalah tehnik yang efektif, dan mortalitas operatif dapat diturunkan, khususnya morbidas kebocoran pankreas yang dapat ditangani. (Med J Indones 2004; 13: 166-70)
\end{abstract}

\begin{abstract}
We reported our experience on 31 pancreaticoduodenectomy out of 141 periampullary tumors during 1994 until 2002 ; 16 of them were female, and age average 17-68 years. Jaundice was the most common presenting sign; 14 patients showed plasma albumin lower than $3.5 \mathrm{~g} / \mathrm{dl}$, and 10 patients had bilirubin level more than $10 \mathrm{mg} / \mathrm{dl}$. We performed classical Whipple technique in 17, pyloric preserving pancreaticoduodenectomy in 11, and total pancreaticoduodenectomy in 3 patients. The mean of operative time was 436 minutes (290-570 minutes). The patients were grouped into 2 periods, between 1994-1999 and thereafter. With experience, the amount of blood loss has decreased from $2000 \mathrm{ml}$ to $400 \mathrm{ml}$. Histopathologic results showed adenocarcinoma of the pancreas head in 11, adenocarcinoma of the ampulla of Vater in 11, carcinoma of duodenum in 4, head of pancreas benign cyst in 2, and benign tumor in 3 patients. The surgical mortality was 4 in the first 12 patients, in contrast to only 1 in the last 19 patients. The most serious complication was pancreatic leakage in 14 patients, in 4 of them it was responsible as the cause of death. The length of stay after operation varied between 12 and 47 days. Until the end of this report 7 patients are still alive, and 4 patients lost of contact. Recurrence was detected in 13 out of 22 survivors, occurring between 4 to 24 months after operation and 12 patients died 2-3 months later. Three patients died due to other causes. We conclude that pancreoticoduodenectomy is an effective technique, and the operative mortality is decreasing. Furthermore, morbidity especially from pancreatic leakages can be treated in our hospital. (Med J Indones 2004; 13: 166-70)
\end{abstract}

Keywords: operative outcome, Whipple technique, pancreatic leakage

Current evidence indicates that pancreaticoduodenectomy is the only hope for long survival of patients with resectable periampullary tumors; there is no promising reports on the use of chemotherapy or radiation therapy in such cases. ${ }^{1,2}$ Periampullary

Division of Digestive Surgery, Department of Surgery, Faculty of Medicine, University of Indonesia / Dr. Cipto Mangunkusumo

Hospital, Jakarta, Indonesia tumors refer to all tumors around the ampulla of Vater which may originate from different tissues but provide similar signs and symptoms and surgical treatment. ${ }^{3}$ These tumors have better resection rate and survival than ductal adenocarcinoma of the pancreas, which was more commonly reported and published. ${ }^{3-5}$

Because of the significant decrease of mortality and the improvement of morbidity care in the last few decades, pancreaticoduodenectomy has become the treatment of choice for periampullary tumor. ${ }^{2,6}$ 
Resection (even palliative resection) gives a better quality of life when compared to endoscopic stenting and palliative by pass surgery. ${ }^{7,8}$

It is predicted that the incidence of periampullary tumors in our country in the coming years is increasing. Nowadays periampullary tumor ranks the third of all gastrointestinal malignancies. Previously malignant jaundice due to periampullary tumors was almost always treated palliatively, i.e., by-pass surgery or endoscopic stenting, which gave poor results. When we just started this procedure the outcome was poor. With increasing interest, better team approach, better patient selection and perioperative care, the result has been increasingly better. This report reviews our experience in treating resectable periampullary tumors at Cipto Mangunkusumo Hospital, Jakarta, which is the national referral hospital of the country.

\section{METHODS}

One hundred and forty one patients with periampullary tumors were hospitalized during 1994 until 2002. They were grouped into 2 periods; in the first period (1994 until 1999) there were 86 patients, and in the second period 55 patients were hospitalized. The grouping were based on the fact that since the mid of 1999 the periampullary tumors cases were well recorded and the team approach system started.

Pancreaticoduodenal resection was performed in thirty one patients, i.e., 12 patients in the first period and 19 in the second period. In the last 19 patients surgery was done by one of the authors. Tight selection and multidiscipline approach were performed before the operation.

The type of resection was decided during operation, the first option was pyloric preserving pancreaticoduodenectomy with standard margin dissection for all malignant periampullary tumors. If the first part of the duodenal wall was found involved, the classic Whipple procedure was performed. Total pancreatectomy was performed if the tumor involved more than half of the pancreas.

\section{RESULTS}

The characteristics of the 31 patients are described in Table 1 . Total bilirubin level was more than $10 \mathrm{mg} / \mathrm{dl}$ on admission in 10 patients. Due to shortage of facilities for endoscopic stenting, cholecystostomy with local anesthesia was performed for drainage and followed by cholangiography for further diagnosis. The preoperative diagnosis were tumor of the head of pancreas in 15, ampulla of Vater tumor in 11, distal common bile duct (CBD) in 4 , and obstructive jaundice in 1 patient.

Pathologic examination showed the final diagnosis were ductal adenocarcinoma of the pancreas in 9 patients (pT1-2No-1Mo), cyst adenocarcinoma of the head of pancreas in 2 (pT2-3No-Mo), adenocarcinoma of the ampulla of Vater in 11 patients (pT1-3No$1 \mathrm{Mo}$ ), adenocarcinoma of the duodenum in 3 patients (pT4-N1-Mo), Signet ring cell carcinoma of duodenum in 1 (pT4-N1-M0), papilla of Vater benign tumor in 2 patients, duodenitis in 1 patient and cystic tumor of the head of pancreas in 2 patients.

Table 1. Characteristics of periampullary tumor patients underwent pancreoticoduodenectomy

\begin{tabular}{lc}
\hline Sex: Male/Female (number of patients) & $14 / 15$ \\
Age range (yrs) & $17-68$ \\
Clinical findings (number of patients) & \\
- Jaundice & 23 \\
- Abdominal pain & 7 \\
• Abdominal mass & 1 \\
Main laboratory features (number of patients) & 10 \\
- Bilirubin > 10 mg/dl & 14 \\
- Albumin < 3.5 g/dl & 22 \\
Preoperative drainage (number of patients) & \\
Imaging investigations (number of patients) & 31 \\
- Ultrasound & 30 \\
- CT-scan & 14 \\
- Endoscopy & 13 \\
$\bullet \quad$ Endoscopic-retrograde- \\
$\quad$ cholangiopancreaticography (ERCP)
\end{tabular}

\section{Types of resection and reconstruction}

We performed classical Whipple procedure in 17 patients, 11 pyloric preserving pancreaticoduodenectomy (PPPD), and 3 total pancreatectomy duodenectomy (Table 2), and most resection were performed in patients with pancreas-head malignancy and ampulla of Vater region malignancy. For reconstruction, single jejunum loop was used. The first step was an end-to-end anastomosis to the pancreas, the second was $10-15 \mathrm{~cm}$ distal end to side anastomosis to the bile duct, and the final step was anastomosis to duodenum or stomach. 
Pancreaticojejunostomy anastomosis were performed by using Dunkin technique. At the beginning we routinely put a stent through the pancreatic duct, but recently no more stent was used.

Blood loss during operation has decreased from 2000 $\mathrm{ml}$ to $400 \mathrm{ml}$ with increasing experience. The blood transfusion (packed red cells) needed during operation remained relatively unchanged, i.e., ranged from 500 to $750 \mathrm{ml}$.

The operative time ranged from 300 to 570 minutes, total pancreatectomy took longer time. At present we need 4 hours for resection and 2 hours more for reconstruction. Stapler or clips is never used.

The post-operative care included ICU stay for 4-5 days and than the patients moved to the ward. Enteral tube feeding was started on day 4 to day 7 . Length of hospital stay varied greatly, namely from 9 to 47 days (mean 23.6 days). The longest hospitalized patient was one with steatorrhea who developed severe malnutrition and the last patient which suffered from relaprotomy due to high out put pancreatic fistula after tube drainage removal.

Table 2. Operative procedure results

\begin{tabular}{ll}
\hline Resection type (number of patients) & \\
Classical Whipple procedure & 17 \\
PPPD & 11 \\
Total pancreatectomy+duodenectomy & 3 \\
\hline Operative time & $300-570$ minutes \\
Blood loss & $2200-400 \mathrm{ml}$ \\
Start of enteral feeding & $4-7$ days p.o \\
I C U stay & $4-7$ days \\
Hospitalization & $9-47$ days p.o. \\
\hline
\end{tabular}

PPPD = pyloric preserving pancreaticoduodenectomy, p.o. $=$ post-operative, $\mathrm{ICU}=$ intensive care unit

The operative mortality decreased from 4 deaths out of 12 patients in the first period, to one operative death in the last 19 patients. One patient died 30 days post operative at internal ward due to prolonged melena which was not treated early. The one patient which died due to melena already recovered well and already started eating; three weeks after operation he suffered melena and was not treated adequately; the patient died due to late complication. We excluded him from the operative death part. The most common complications found were wound infection, pancreatic fistula, and pneumonia (Table 3). Delayed gastric emptying occurred in 3 patients, in one patient the delay was as long as 1 month. Marginal ulcer was successfully managed with anti H2 blocker. Out of 13 patients with pancreatic leakage, in the first 4 the leakage was considered to be responsible as the cause of death. However, the subsequent 8 patients healed spontaneously with good tube drainage. The longest leakage healing was 21 days. One of the last patient that went for relaparotomy due to high out put pancreatic fistula after drain tube removal survived and went home 1 month after.

The patient with steatorrhea was treated with elemental diet and oral enzyme support. He suffered also from severe malnutrition, which prolonged the hospital stay.

Table 3. Complications following surgical intervention

\begin{tabular}{lc}
\hline Complications & Numer of patients \\
\hline Pancreatic Fistula & 13 \\
Biliary fistula & 0 \\
Wound Infections & 10 \\
Pneumonia & 8 \\
Delayed Gastric emptying & 3 \\
Marginal Ulcer & 1 \\
Steatorrhea & 1 \\
Postoperative Haemorrhage & 1 \\
\hline
\end{tabular}

Note: One patient might have more than one complication

Regarding patient's survival, we noted that in the first period two patients with carcinoma of the ampulla of Vater were disease free more than 60 months. The others died of recurrent tumor between 6-22 months after operation. During the period of 1999-2002 there were 22 survivors, among them 7 were alive until present and two patients were lost of contact in that period. The longest survival was 24 months, i.e., a patient with adenocarcinoma of the papilla of Vater (pT2-No-Mo). Nine patients died due to recurrence which occurred between 3 and 18 months. The longest disease free was noted in a patient with adenocarcinoma of the ampulla of Vater (pT1-No-Mo). One patient died 3 months after operation due to refractory hypoglycemia. The other one patient died of a cause not related to the disease at home 1 month after discharged. The last one died 1 month after operation still in the hospital, but not in surgery department due to melena. 
In our series, ampulla of Vater malignancy had better survival (24 months) compared to pancreas-head malignancy.

\section{DISCUSSION}

In 1960's pancreaticoduodenectomy was abandoned due to poor outcome; the overall operative mortality were around $25-35 \%,{ }^{9-12}$ but by the end of the last century the operative mortality decreased significantly to below 5\%, some centers reported no mortality on 100 pancreaticoduodenectomy resection. ${ }^{5,6,10,11}$ The decreasing mortality was due to a good patient selection, multidisciplinary team approach, experience of the surgeons, good technique and aggressive work against complications. ${ }^{10-12 .}$ There are strong correlations between number of patients with periampullary tumors with operative mortality, morbidity and survival. ${ }^{12-14}$

It is clearly seen in our series that in the first period, due to limited experience and less careful selection of cases the mortality was high, i.e. 4 operative deaths occurred in the first 12 patients; most of deaths were related to sepsis following pancreatic leakage. One death in the last 19 patients was due to prolonged shock which was not managed adequately during and after operation. The patient died 48 hours after operation. The mortality was decreasing with increasing experience. Since 1999 our department organized the surgical team and multidisciplinary team approach to manage resectable periampullary tumor, and by the end of year 2000 we have noticed some promising results. The periampullary cases and resection rate increased, including a 68 year old patient with carcinoma of the ampulla of Vater who was successfully operated and survived for 19 months before expired due to recurrent tumor. This means that age more than 60 is not a contraindication to perform curative resection as long as the patient condition is good.

In our series, obstructive jaundice was the most common presenting sign with high direct bilirubin level. Low albumin content due to poor intake was found in a large proportion of the patients. In these patients decompression was first done by cholecystostomy with local anesthesia because endoscopic retrograde cholangiopancreoticography (ERCP) cannot be performed routinely. The next step was cholangiography via the external tube, and abdominal ultrasound examination for detecting metastasis. At this point usually diagnosis and stage of the disease could be confirmed. The next step was assessment of the resectability with abdominal CT scan. We found that almost all patients preoperatively judged to be resectable by CT scan were proven resectable at operation.

From our point of view it is important to decompress the bile duct preoperatively since many of our cases came with very high total bilirubin level (more than $15 \mathrm{mg} / \mathrm{dl}$ ) which has been suffered for more than 1 month. It is the same with Keith Lillemoe's report. ${ }^{15}$ During the bile decompression, nutrition support was started by oral and parenteral route. What was specific in our series was that the decompressed bile was refed orally to help the digestive process. Our great concerns were fluid balance and blood loss during operation, since it strongly influenced the outcome.

In these series we performed classic Whipple procedures in 17 patients, PPPD in 11 patients, and total pancreaticoduodenal resections in 3 patients. Total pancreatectomy needed longer operative time. The apancreatic diabetic was managed successfully by endocrinologists. There was no difference of outcome between pancreaticoduodenectomy and PPPD for resectable periampullary malignancy as long as the radical protocol was followed. ${ }^{16-18}$

In most series, pancreatic leakage was one of the fatal complications which could result in death. Recent studies indicated that the incidence of pancreatic leakage was between $6-25 \%$, and $26 \%-40 \%$ of these leaks were directly responsible for patient's death. ${ }^{19,20 .}$ In our study, in the first and second periods, the 4 pancreatic leakages ended with death due to sepsis \& multiple organ failure (MOF), but leakage in 9 out of the last 18 patients healed spontaneously simply by adequate drainage. The last patient needs surgery due to high out put pancreatic fistula. This experience lead us to put routinely draining tube around the pancreatic jejunostomy anastomosis that guarantee an adequate drainage. The tube was removed after ten days if the production were minimal. Aggressive surgery intervention was also good attitude against morbidity. We did not use octreotide or somatostatin in our patients. We need to improve anastomosis technique to the pancreas to decrease the leakage incidences. Delayed gastric emptying was successfully treated with prolonged nasogastric tube and oral erythromycin in 3 cases. $^{20,21}$ 
In our series, ampulla of Vater malignancy had better survival (24 months) compared to pancreas-head malignancy. This fact is in line with those that were reported in other studies. ${ }^{3,6}$

We concluded that pancreaticoduodenal resection gave better outcome in patients with periampullary tumors when compared to previous practice in our hospital. Operative mortality decreased even the incidence of morbidity were still high, but all could be treated.

\section{REFERENCES}

1. Wagner M, Friess H, Buchler MW. Conservative versus radical resections of the pancreas. In: Neoptolemos JP, Lemone NR, editors. Pancreatic cancer - molecular and clinical advances. London: Blackwell science; 1996. p. 248-63.

2. Yeo CJ, Abrams RA, Grochow LB, Sohn TA, Sarah EO, Hruban RH, et al. Pancreaticodoudenectomy for pancreatic adenomacarcinoma: Postoperative adjuvant chemoradiation improves survival. Ann Surg 1997;225:621-36.

3. Ihse I, Andersson R, Axelson J, Kobari M, AndrenSandberg A. Periampullary tumors. In: Neoptolemos JP, Lemoine NR, editors. Pancreatic cancer, molecular and clinical advances. London: Blackwell Science; 1996. p. 328-35.

4. Lillemoe KD, Kal Sauter P, Pitt H, Yeo CJ, Cameron JL. Current status of surgical palliation of periampullary carcinoma. Surg Gynec Obststet 1993;176:1-9.

5. Shyr Ming Y, Hsi Su C, Chung Wang H, Shun Lo S, Yiu Lui W. Comparison of resectable and unresectable periampullary carcinoma. J Am Coll Surg1994;178: 369-78.

6. Yeo CJ, Cameron JI, Sohn TA, Sarah EO, Lilemoe KD, Pitt H, et al. Six hundred fifty consecutive pancreaticoduodenectomies in the 1990s. Ann Surg 1997;226:248-60.

7. Lillemoe KD, Barnes SA. Surgical palliations of unresectable pancreatic carcinoma. Surg Clin North Am 1995;75:952-62.

8. Carter DC. Indications for surgery. In: Neoptolemos JP, Lemoine NL, editors. Pancreatic cancer, molecular and clinical advances. London: Blackwell science; 1996. p. 237-47.
9. Kellum JM, Clark J, Miller HH. Pancreaticoduodenectomy for resectable malignant periampullary tumor. Surg Gynec Obstet 1983; 157:362-6.

10. John M, Howard JM. Historical aspects and the future of pancreaticoduodenectomy. In: Hanyu F, Takasaki K, editors. Pancreaticoduodenectomy. Berlin: Springer; 1995. p. 3-10.

11. Pitt HA. Curative treatment for pancreatic neoplasm standard resection. Surg Clin North Am 1995;75:891-901.

12. Gouma DJ, Obertop H. Centralization of surgery for periampullary malignancy. Br J Surg 1999;86:1361-2.

13. Gordon TA, Bowman HM, Tielsch JM, Bass EB, Burleyson GP, Cameron JL. Statewide regionalization of pancreaticoduodenectomy and its effect on in-hospital mortality. Ann Surg 1998;228:71-8.

14. Birkmeyer JD, Warshaw AL, Finlayson SRG, Grove MR, Toesteson ANA. Relationship between hospital volume and late survival after pancreaticoduodenectomy. Surgery 1999;126:178-83.

15. Lillemoe KD. Preoperative biliary drainage and surgical outcome. Ann Surg 1999;230:143-4.

16. Takao S, Aikou T, Shinchi H, Uchikura E, Kubo M, Imamura $\mathrm{H}$, et al. Comparison of relapse and long-term survival between pylorus preserving and Whipple pancreaticoduo-denectomy in periampullary cancer. Am J Surg 1998;176:467-9.

17. Allema JH, Reinders MER, van Gulik TM, Koelemay MJW, Van Leeuwen DJ, de Wit L Th, et al. Prognosis factors for survival after pancreaticoduodenectomy for patients with carcinoma of the pancreatic head region. Cancer 1995;75:2069-76.

18. Zerbi A, Balzano G, Patuzzo R, Calori G, Braga MV, Di Carlo V. Comparison between pylorus preserving and whipple pancreatoduodenectomy. Br J Surg 1995;82:975-9.

19. van Berge Henegouwen MI, de Wit L Th, van Gulik TM, Obertop H, Gouma DJ. Incidence, risk factors, and treatment of pancreatic leakage after pancreaticoduodenectomy: drainage versus resection of the pancreatic remnant. Am Coll Surg 1997;185:18-24.

20. Yeo CJ. Management of complications following pancreaticoduodenectomy. Surg Clin North Am 1995; 75:913-22.

21. van Berge Henegouwen I, van Gulik TM, de Wit L Th, Allema JH, Rauws EAJ, Obertop H, et al. Delayed gastric emptying after standard pancreaticoduodenectomy versus pylorus preserving pancreaticoduodenectomy: an analysis of 200 consecutive patients. J Am Coll Surg 1997; 185:373-9. 